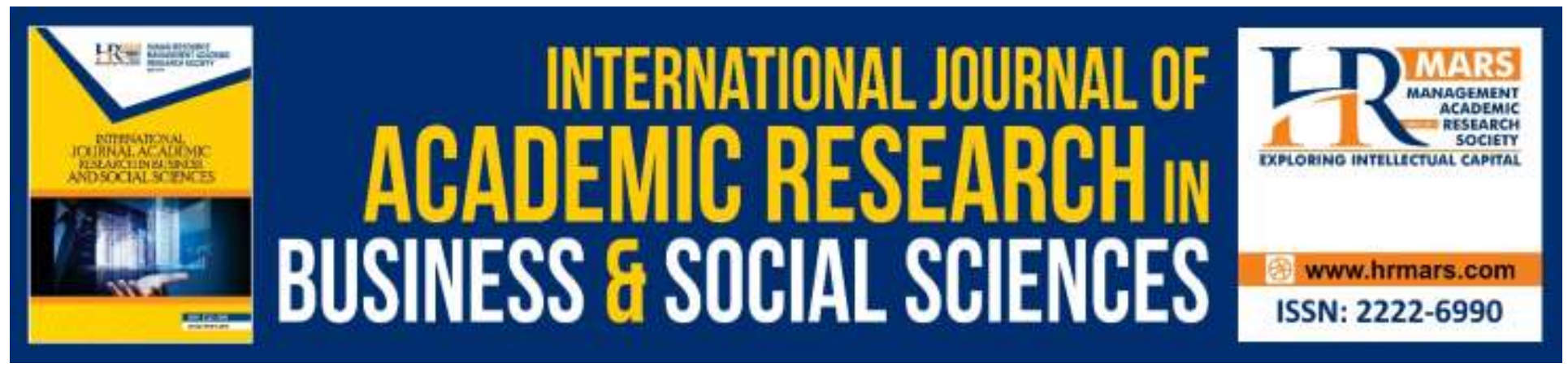

\title{
Exploring Career Development Experiences Among Working Spouses in Dual-Career Family Situations
}

\author{
Norshila Mohd Hamin \& Nur Aira Abdrahim
}

To Link this Article: http://dx.doi.org/10.6007/IJARBSS/v9-i11/6705

DOI: $10.6007 /$ IJARBSS/v9-i11/6705

Received: 01 October 2019, Revised: 24 October 2019, Accepted: 06 November 2019

Published Online: 23 November 2019

In-Text Citation: (Hamin, \& Abdrahim, 2019)

To Cite this Article: Hamin, N. M., \& Abdrahim, N. A. (2019). Exploring Career Development Experiences Among Working Spouses in Dual-Career Family Situations. International Journal of Academic Research in Business and Social Sciences, 9(11), 1360-1371.

\section{Copyright: (C) 2019 The Author(s)}

Published by Human Resource Management Academic Research Society (www.hrmars.com)

This article is published under the Creative Commons Attribution (CC BY 4.0) license. Anyone may reproduce, distribute, translate and create derivative works of this article (for both commercial and non-commercial purposes), subject to full attribution to the original publication and authors. The full terms of this license may be seen at: http://creativecommons.org/licences/by/4.0/legalcode

Vol. 9, No. 11, 2019, Pg. 1360 - 1371

Full Terms \& Conditions of access and use can be found at http://hrmars.com/index.php/pages/detail/publication-ethics 


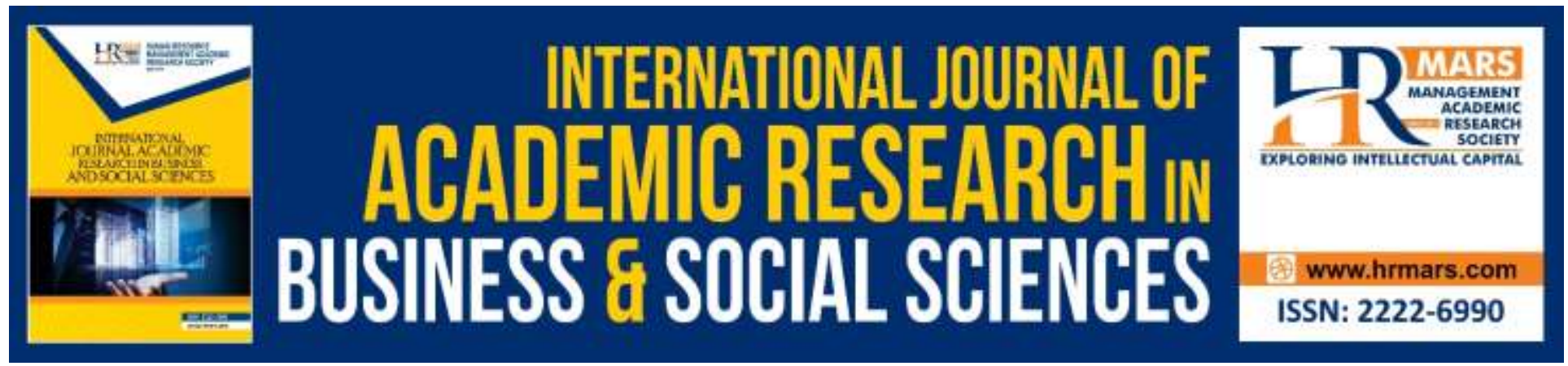

\title{
Exploring Career Development Experiences Among Working Spouses in Dual-Career Family Situations
}

\author{
Norshila Mohd Hamin \& Nur Aira Abdrahim \\ Department of Professional Development \& Continuing Education, Faculty of Educational \\ Studies, Universiti Putra Malaysia (UPM), Malaysia
}

\begin{abstract}
This paper discusses the career development experiences among working spouses in dual-career family (DCF) situation. The purpose of this research was to understand the experiences and contributing factors that made spouses chose to be in dual-career family situation, as well as their perceptions on the benefits and challenges of DCF on their career development. This research was conducted using an exploratory qualitative method. Findings indicate that being in a dual-career relationship impacts how working spouses made decisions regarding their family responsibilities and career priorities within the family unit. The experiences described by the participants reflect the salience of their family and work roles in parallel to one another, thus creating unique career development pathways. The findings also revealed the inseparable worlds of work and family experienced by DCF couples, including the challenges faced and how they coped with it in order to advance in their career development.
\end{abstract}

Keywords: Career Development, Dual-Career Family, Dual-Career Spouses, Working Spouses.

\section{Introduction}

Over the past two decades, there has been an increase in the number of individuals, both men and women, with significant responsibilities at work and with family (Carnicer, Sanchez, Perez, \& Jimenez, 2004; Okeke, Mbonu, Ndubuisi, 2018). The changing status of women in the society in the last half of the twentieth century has been the main reason for the reconfiguration of the traditional families. Prior to that, women were naturally given the responsibility related to household chores and family care; whereas men were mainly tasked as the family breadwinner. During that time, there was an obvious division of labour existed, where men provide for the needs of the family (mostly monetary provision), whilst women perform the role of caregiver and handling the household duties. The scenario has since shifted, where women are now entering the world of working outside from home, thus changing the nature of family's duties (Ugwu, 2009). Traditional family structures, gender role prescriptions, and the division of domestic labor 
have been extensively impacted by the shifting economic and social circumstances. More and more married women began to engage in paid employment outside the home (Elloy \& Smith, 2003). This type of restructuring of personal relationships has given rise to the surfacing of dualcareer families in the society.

Dual career family (DCF) refers to a couple who are married with children and live together, where both currently employed outside of home (Ugwu, 2009; Ahmad, Mokshein, \& Husin, 2018). Various similar terms have been identified in the literature referring synonymously to DCF, such as dual-earner family (e.g. Winkler, 1998; Waite and Nielsen, 2001) and dual-worker family (e.g. Rizzo, 2009). Some authors also used the term "couples" instead of "family", for example, dual-earner couples (e.g. Bartley et al., 2005; Haddock et al., 2006; Brennan, 2011), and dual-career couples (e.g. Bures et al., 2011; Lian, 2008). Since most of these studies were primarily conducted in the Western setting, couples may also refer to two individuals who are not married, but living together, with or without children. Since this study was conducted in a Malaysian setting, the researchers chose to use the term dual-career family based on Ugwu's (2009) definition, referring to a working couple who are married, live and have children together.

The dual-career relationship between two individuals reflect the complex interaction of career and gender roles in the modern society (Elloy \& Smith, 2003). When both members in a committed relationship have a career, personal lives can be complicated and become intertwined with the individuals' occupational lives. Being in dual-career lifestyle also highlights three critical issues; namely career-related issues, family-system issues and individual issues (Kargewell, 2008). Career-related issues refer to the tendency for conflicts to occur between the needs of one spouse's career and the needs of the other's. As for family-system issues, it discusses about the division of roles, the division of power as well as marriage and family satisfaction. Meanwhile, individual issues concern the conflicts that are related to the gender roles for each spouse.

Previous research suggests that most of the success of the dual-career family is due to the couples' willingness to move away from traditional gender role norms and find creative solutions to the dilemmas faced in their daily lives involving both work and family. Because more and more women are entering the workforce, this has led to the need for change in terms of partner's roles in the relationship (Spiker-Miller \& Kees, 1995). Partners in dual-career relationships develop a common understanding on the role behaviors of their family unit through role-taking interactions (Budworth, Enns \& Rowbotham, 2008). In today's world, women are increasingly dealing with career-related demands while preserving their family roles. As for men, they are becoming more involved in family roles since they need to balance their roles between work and family, particularly if their spouses are working too. This is a clear illustration of how integral and inseparable the worlds of work and family have become, especially for couples in dual-career family setting (Smith, 1997).

There are many reasons why people choose to be in a dual-career situation. Theunissen, Van \& Visser (2003) suggest one of the reasons may be to obtain a higher standard of living and the needs to customize a career path. Many women, including those with young children, entered the job market to earn their own income due to economic needs and desire for financial 
independence. According to Elloy \& Smith (2003), working provides an opportunity for individuals to achieve their personal fulfilment and financial rewards. Thus, in DCF situation where each spouse earns an individual income, this enables them to provide better means for their children and help their families achieve lasting economic stability (Bernadi, 1999; Julian \& Kominski, 2011). In Malaysia in particular, the median monthly household income of Malaysians (as of 2016) is around RM5,000 (The Star Online, 2017). Most dual-career families have fully furnished house (mortgage payment), have at least a car (two cars are becoming increasingly common in each household), utilities, and at least two children to support, if not more. Due to financial demand in the standard of living, both spouses need to work and contribute to the family's economic needs, thus dual-career families are becoming increasingly common here in Malaysia.

Additionally, past researchers also stated that dual-career couples are usually highly educated; thus social recognition is also regarded as one of the reasons why couples chose to work. Some identified as being a role model, especially to their children. Highly educated parents can provide aspiration for career pathways for their own children, as they can influence their children's career and life choices (Domenico \& Jones, 2006). In fact, the society recognize them as individuals who are not only financially stable with high education level, but also have good parenting style and socialize well with others.

However, Spiker-Miller \& Kees (1995) noted that although being on the job provides individuals with a lot of economic and psychological benefits, it also creates many pressures and stresses, especially among dual-career families. According to Stockard (1990), work family conflict had an impact on career progression either to men or women. Thus, the conflict may increase the pressure in developing career, especially when couples struggle to balance their work life and family responsibility. Due to family demands, some couples or individuals tend to have difficulties in coping with competitive trend at their workplace, and distort their career growth (Segal, 2005). Therefore, achieving work-life balance is key among working professionals in DCF situations, where couples made decision and negotiate the time and efforts between their work and family.

During the past decade, due to the growing number of women entering the workforce, past research has focused primarily on woman perspectives in regards to their career challenges instead of men. For example, a research done by Wood \& Lindroff (2001) was on the barriers of career development reported by women. Previous studies also focused more on the problems of dual-career families faced solely from women's perspectives. For example, according to Lirio (2007), working women were also responsible for handling their family management and children care. Eventually, some of them decided to leave the workforce due to the struggle in combining complex routines between work and household responsibilities.

However, the experiences and conflicts faced by men in dual-career families typically varied due to gender perspectives and different role expectations. In a pioneer research conducted among 16 dual-career families, Rapoport \& Rapoport (1969) reported that most DCF experienced gender specific challenges and dilemmas in their lives. Due to the challenges that came from balancing their work and family, one of the spouses usually have to sacrifice and take a setback in their career. It is usually mothers who had to reduce their career involvement to 
alleviate work-family conflict such as turning down opportunity for career advancement and promotion that requires higher responsibility and commitment, cutting back on work hours, refusing promotions that require relocations and putting their career 'on-hold' (Cherpas, 1985). However, women could have both a career and raise a family as long as their husbands are supportive and willing to have shared responsibility in raising and caring for the family.

All these past research serve as a guideline for further research on this topic in Malaysia context. Specifically, this study was guided by three research questions:

1. What are the contributing factors that made couples chose to be in dual-career families situation?

2. What are the perception of couples regarding the benefits and challenges of being DCF on their career development?

3. How do dual-career families overcome the challenges faced in their career development?

\section{Theoretical Framework}

This research used the Kaleidoscope Career Model (KCM) as the theoretical framework to guide the study. Although the KCM was first introduced as an alternative lens to look at women's career development, it has been examined from both men and women's perspectives in past empirical research (Cabrera, 2007; Sullivan \& Mainiero, 2007). There are three career parameters that formed the basis of KCM; authenticity, balance, and challenge (Mainiero \& Sullivan, 2005).

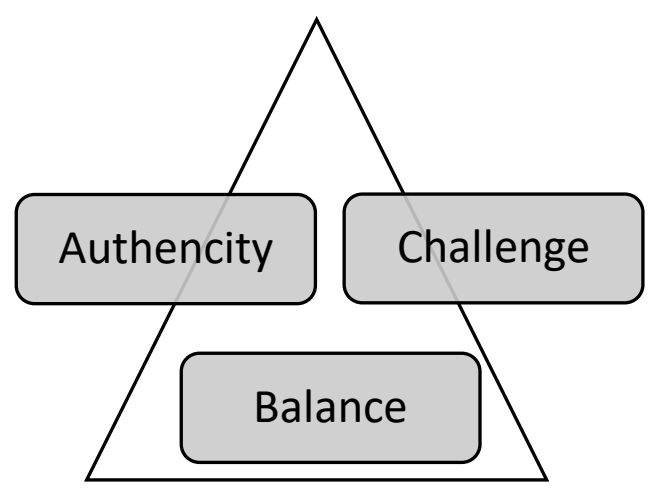

Figure 1. Kaleidoscope Career Model

These parameters reflect the premise in which men and women made decisions regarding their career development. Sullivan \& Mainiero (2008) define each of these parameters as follow:

1. Authenticity - defined as being true to oneself in the midst of constant interplay between personal development and work and nonwork issues;

2. Balanced - defined as making decisions so that these different aspects of one's life, both work and nonwork, form a coherent whole; and 
3. Challenge - defined as engaging in activities that permit the individual to demonstrate responsibility, control, and autonomy while learning and growing

(Sullivan \& Mainiero, 2008, p. 7)

These three parameters are also referred to as the ABCs of Kaleidoscope. Like a kaleidoscope, career is characterized as dynamic and in motion; as life changes, individuals will alter their career involvement to adjust to these changes, rather than relinquishing control and letting job demands dominate their lives. The combination of these three parameters, like three mirrors inside the kaleidoscope, represent the different ways individuals lead their career decision at different points in lives (Mainiero \& Sullivan, 2005). This because "certain issues predominate at different points in the life span, usually one parameter takes center stage, with the remaining parameters remain active but take on a secondary role at that point in time" (Sullivan \& Mainiero, 2008, p. 8).

Using the parameters in $\mathrm{KCM}$, this study seeks to explore the experiences of couples in DCF on the integration of their work and life as part of their career development pathways.

\section{Method}

This study used the exploratory qualitative research design (Merriam, 2009). Because the purpose of this study requires in-depth exploration on the topic of DCF, the sample selection were a small number of participants with the appropriate information power (Malterud, Siersma, \& Guassora, 2015) Eight participants (i.e. four couples) who met the criteria defined as DCF were selected for this study. All couples are married, lived and have children together, with both spouses having a career of their own with a minimum of five years working experiences. All participants in this study work as government employees in Malaysia.

The primary data collection was conducted using in-depth interviews. Although the unit of analysis in this study was couples in DCF, the interview was conducted separately for each husband and wife. This is to ensure that information solicited during the interviews were not influenced by the present of the other spouse. For verification of accurate information being collected and interpreted, all transcripts and preliminary findings went through a member's check process with the participants.

Data were thematically analyzed as guided by the research questions. The analysis went through an iterative process of coding, sorting, and identifying the themes into meaningful findings. All identifying information were anonymize to protect the confidentiality of all participants, prior to presentation of the findings.

\section{Findings}

A total of eight participants, representing four DCF couples participated in this study. Table 1 (next page) shows the profiles of these participants, including information about their jobs and families. Six out of the eight participants work as teachers at government public schools, whereas two other male participants work as officers in armed forces. All couples had at least 
one child that are still in schooling age. Years of service in their respective career ranged between 6 to 30 years of services. It was also noted that the couples' years of service do not necessarily equate to years of them being in DCF situations.

Table 1. Demographic Profiles of Study Participants

\begin{tabular}{|c|c|c|c|c|c|c|c|}
\hline $\begin{array}{c}\text { Participant } \\
\text { S }\end{array}$ & Gender & $\begin{array}{c}\mathrm{Ag} \\
\mathrm{e}\end{array}$ & Profession & $\begin{array}{c}\text { Educatio } \\
\text { n Level }\end{array}$ & $\begin{array}{c}\text { Years } \\
\text { of } \\
\text { servic } \\
\text { e } \\
\text { (years } \\
\text { ) }\end{array}$ & $\begin{array}{l}\text { No. of } \\
\text { Children } \\
\text { \& Age }\end{array}$ & $\begin{array}{c}\text { Years } \\
\text { of } \\
\text { being } \\
\text { DCF }\end{array}$ \\
\hline \multirow[t]{2}{*}{ Couple 1} & $\begin{array}{c}\text { Husban } \\
\text { d }\end{array}$ & 32 & $\begin{array}{c}\text { Teacher } \\
\text { (Ministry of } \\
\text { Education) }\end{array}$ & Degree & 8 & \multirow{2}{*}{$\begin{array}{l}2 \text { children; } \\
\text { aged } 5 \text { \& } 1\end{array}$} & \multirow{2}{*}{6} \\
\hline & Wife & 31 & $\begin{array}{c}\text { Teacher } \\
\text { (Ministry of } \\
\text { Education) }\end{array}$ & Degree & 6 & & \\
\hline \multirow[t]{2}{*}{ Couple 2} & $\begin{array}{c}\text { Husban } \\
\text { d }\end{array}$ & 52 & $\begin{array}{c}\text { Teacher } \\
\text { (Ministry of } \\
\text { Education) }\end{array}$ & Diploma & 30 & \multirow{2}{*}{$\begin{array}{c}5 \text { children; } \\
\text { aged } 24, \\
23,21, \& \\
10\end{array}$} & \multirow{2}{*}{25} \\
\hline & Wife & 49 & $\begin{array}{c}\text { Teacher } \\
\text { (Ministry of } \\
\text { Education) }\end{array}$ & Diploma & 24 & & \\
\hline \multirow[t]{2}{*}{ Couple 3} & $\begin{array}{c}\text { Husban } \\
\text { d }\end{array}$ & 38 & $\begin{array}{c}\text { Police } \\
\text { (Ministry of } \\
\text { Home Affairs) }\end{array}$ & SPM & 16 & \multirow{2}{*}{$\begin{array}{c}4 \text { children; } \\
\text { aged } 13 \\
10,7, \& 3\end{array}$} & \multirow{2}{*}{14} \\
\hline & Wife & 40 & $\begin{array}{c}\text { Teacher } \\
\text { (Ministry of } \\
\text { Education) }\end{array}$ & Diploma & 19 & & \\
\hline \multirow[t]{2}{*}{ Couple 4} & $\begin{array}{c}\text { Husban } \\
\text { d }\end{array}$ & 46 & $\begin{array}{c}\text { Soldier } \\
\text { (Ministry of } \\
\text { Defense) }\end{array}$ & SPM & 25 & \multirow{2}{*}{$\begin{array}{c}2 \text { children; } \\
\text { aged } 15 \& \\
7\end{array}$} & \multirow{2}{*}{16} \\
\hline & Wife & 42 & $\begin{array}{l}\text { Teacher } \\
\text { (Ministry of } \\
\text { Education) }\end{array}$ & Diploma & 18 & & \\
\hline
\end{tabular}

\section{Themes}

Theme 1: Factors contributing to couples choosing to be DCF

The first theme highlights the reasons why couples chose to be in DCF situations. Reasons discussed include achieving self-interest, fulfilling economic needs, as well as receiving 
organizational support.

Most of the couples stated that being in dual-career families were the decisions made mutually between both the husband and wife. Contrary to the traditional view of women's job as homemaker, women in this study wanted to work and have their own career to fulfill their self-interest in achieving their childhood ambition and conveying knowledge and skills through their jobs. One participant noted that she "do[es] not want to let go of the knowledge that I have learned (throughout all my formal education) just like that...so I work to convey the knowledge I have to my students because I like to teach people and love doing this job" As for the husbands, letting their wives fulfilled their self-interest to have a career was seen as being supportive to their wives' psychological needs; it keeps the marriage steady and economically beneficial to the family too.

As all participants were living in the main cities of Malaysia (Kuala Lumpur, Putrajaya \& Ipoh, all of them also talked about the high cost of living that made being DCF became almost necessary due to their economic needs. The women perceived that their husbands' earnings are not comfortably sufficient for the family; thus by working, these women believed it helped their family achieve financial stability, especially in the case of rising living cost and/or unexpected circumstances or life exigencies. In the words of one of the husbands, "One of the reasons why I agreed for the both of us, especially my wife to work after we got married, is because we're afraid if something bad happen to me, at least my wife have a job, and can survive and care for the children."

At the same time, receiving the necessary organizational support, sustained through government's family friendly policies and benefits to their employees, was also noted as important. For the women, they perceived the government of Malaysia provide equal employment and career development opportunities regardless of gender, and thus supported their needs to stay in employment, even though they are married and have children. Furthermore, the government has also introduced numerous family-friendly policies that helped alleviate the conflicts between family-work faced by DCF couples, such as flexible working hours, 90-days paid maternity leave, quarantine leave (for parents whose children contracted an infectious disease), and extended leave to care for sick/nursing children. Therefore, under various circumstances where conflicts arise between their job and family, these couples reported that they have always been able to manage the situations throughout their careers.

Theme 2: Benefits \& challenges as DCF

Couples in this study have been in DCF situation for almost as long as their marriage, the shortest being 6 years while the longest was 25 years. Naturally, the overall experiences were described both in the context of positive and negative experiences; highlighting benefits as well as challenges they faced as DCF couples.

Overall, all couples in this study reported that they are satisfied with their current life configuration as DCF because it was seen as a self-achievement not only for one, but both spouses. With each of them having a career and job of their own, they perceived their family as being financially stable and living comfortably. This sense of security thus contributed to their life 
satisfaction as a married couple. Financial stability, therefore, was also highlighted as a key benefit. The women spoke of their willingness to share the responsibility of being a financial provider, especially in providing additional support to their growing family. Some women also spoke about their voluntary contribution to invest in their children's education using their hardearned money. As for the men, it lessens their financial worries knowing that their spouses are also bringing financial contribution to the family, in case of any shortcoming or increasing financial needs. Furthermore, being working parents was also seen as bringing positive aspiration to their children. These couples, hoped to convey positive influence to their children, especially on their children's career pathways as well as motivating their children to work hard in their studies to achieve the career that they wish for.

Meanwhile, challenges as DCF include uneven domestic responsibility between the spouses, and ongoing work-family conflicts. The women in particular, felt there are differences in being career women versus career men, as the weightage of domestic responsibility falls more on the wives/mothers. Some also shared how the nature of their husbands' jobs (who work in armed forces) made it even more challenging because their spouses are often away and work long hours. Even the men felt it was usually more challenging for their wives, even when they helped out at home, due to their wives' own expectations of their role responsibilities. One male participant said, "Although sometimes I still help my wife manage domestic chores and the children, she still does everything to ensure the role she plays as mother and wife is successful in my eyes.." In addition, being DCF complicates the schedules and routines for everyone in the family, as each spouse have their own work demand, that comes in parallel with their family needs. Conflicts between work and family often clash, and DCF couples sometimes faced dilemmas in terms of deciding between them, who to take charge of the family while the other pursue their work commitment as usual.

Theme 3: Coping \& overcoming challenges as DCF

After being in DCF situation for years, the couples also shared their coping strategies to overcome the challenges they faced. One of the key strategies is to practice work-life integration between the demands of their careers as well as family needs. This was typically achieved through constant negotiation and communication between the spouses, especially to find common ground and agreement on the changing responsibility. The most important thing the couples reported was on being flexible with the shared responsibilities, as things and routines are always changing between their work and family domains. Couples also reported that during working days, certain things have to be compromised (such as eating takeaway food), but compensation will be made thereafter during weekends and holidays.

Furthermore, establishing key support system, not only between one another, but also among immediate family and colleagues are also significant for DCF couples. Immediate family (such as parents, parents in law, or siblings) can help out with family care, whereas colleagues may help to provide support at work. Put together, it strengthens the DCF family's support system to ease their burden during time of work-home conflicts. 


\section{Conclusion}

The findings shed lights on the perspectives of both men and women in DCF situation. The experiences reported by these couples are consistent with previous literature on the dynamic nature of career development as influenced by various work and nonwork factors (Sullivan \& Mainiero, 2007). For DCF couples, due to the nature of their work-life integration, their career development does not typically progress in a linear way, but rather, presents a unique pattern at different stages of their lives (Sullivan \& Mainiero, 2008). For the women in particular, role expectations placed on themselves by themselves, made their experiences different than their husbands. Although it was not described in negative ways, both women and men agreed that women typically faced more challenges in their career development due to the women's own attachment to their role responsibility as wife and mother.

This study also highlights the importance of supportive employer's policies and familyfriendly practices to support working parents, especially those in DCF situations, to cope with their work-life conflicts. For these employees, their commitment to work was never seen as secondary despite having family and children. Rather, it was about achieving a well-integrated work-life balance to make them become a productive worker, as well as good spouse/parent. More importantly, with effective work-life integration practices and support at the workplace, more sustainable career development can be achieved in the long run for these employees.

\section{Corresponding Author}

Nur Aira Abdrahim (PhD), Department of Professional Development \& Continuing Education, Faculty of Educational Studies, Universiti Putra Malaysia (UPM), Malaysia

Email: nuraira@upm.edu.my

\section{References}

Bartley, S. J., Blanton, P. W., and Gilliard, J. L. (2005) Husbands and wives in dual-earner marriages: decision-making, gender role attitude, division of household labour and equity. Marriage and Family Review, 37(4), 69-74.

Bernardi, F. (1999). Does the husband matter: Married women and employment in Italy. European Sociological Review, 15(3), 285-300.

Brennan, R. T., Barnett, R. C., and Gareis, K. C. (2001). When she earns more than he does: a longitudinal study of dual-earner couples. Journal of Marriage and Family, 63 (1), 168182.

Budworth, M., Enns, J., \& Rowbotham, K. (2008). Shared identity and strategic choice in dualcareer couples. Gender in Management, 23(2), 103-119.

Bures, A. L., Henderson, D., Mayfiled, J., Mayfiled, M., and Workey, J. (2011). A cross national investigation of dual-career couples. Journal of Applied Business Research, 12(1), 52-58.

Cabrera, E. F. (2007). Opting out and opting in: understanding the complexities of women's career transitions. Career Development International, 12, 218-227.

Carnicer, M. P., Sa'nchez, A. M., Pe'rez, M. P., \& Jime'nez, M. J. (2004). Work-family conflict in a Southern European country: The influence of job-related and non-related factors. Journal 
of Managerial Psychology, 19(5), 466-489.

Cherpas, C. C. (1985). Dual-career families: Terminology, typologies, and work and family issues. Journal of Counseling and Development, 63(10), 616-620.

Domenico, D. M., \& Jones, K. H. (2006). Career aspirations of women in the 20th century. Journal of Career and Technical Education, 22(2), 1-7.

Elloy, D. F., \& Smith, C. R. (2003). Patterns of stress, work-family conflict, role conflict, role ambiguity and overload among dual-career and single-career couples: An Australian study. Cross Cultural Management: An International Journal, 10(1), 55-66.

Haddock, S. A., Zimmerman, T. S., and Ziemba, S. J. (2006) Practices of dual earners couples successfully balancing work and family. Journal of Family and Economic Issues, 27 (2): 207234.

Julian, T., \& Kominski, R. (September 2011). Education and Synthetic Work-Life Earnings Estimates. American Community Survey Reports. Retrieved from the U.S. Census Bureau website: http://www.census.gov/prod/2011pubs/acs-14.pdf

Kargewell, S. (2008). Is the glass ceiling kept in place in Sudan? Gendered dilemma of the worklife balance. Gender in Management: International Journal, 23(3), 209-224.

Lian, T. C. (2008). Effects of dual-career and marital conflict on the mental health of couple. Journal e-Bangi, 3(1),1-14.

Lirio, P., Lituchy, T. R., Monserrat, S. I., Olivas-Lijan, M. R., Duffy, J. A., Fox, S., Gregory, A., Punnett, B. J., \& Santos, N. (2007). Exploring career-life success and family social support of successful women in Canada, Argentina and Mexico. Career Development International, 12(1), 28-50.

Mainiero, L. A., \& Sullivan, S. E. (2005). Kaleidoscope careers: An alternate explanation for the opt-out revolution. Academy of Management Executive, 19(1), 106-123.

Malterud, K., Siersma, V. D., \& Guassora, A. D. (2015). Sample size in qualitative interview studies: Guided by information power. Qualitative Health Research, 26(13), 1753 - 1760. doi: $10.1177 / 1049732315617444$

Merriam, S. B. (2009). Qualitative research: A guide to design and implementation. San Francisco, CA: Jossey-Bass.

Rapoport, R., Rapoport, R. N. (1969) The dual-career family: A variant pattern and social change. Human Relations, 22(1), 3-30.

Rizzo, S. (2009) The dual-career worker family: Combining working life with social-life. Bank of Valletta Review, 39, 1-19.

Smith, C. R. (1997). Career transitions of dual-career couples: An empirical study. Career Development International, 2(5), 229-237.

Spiker-Miller, S., \& Kees, N. (1995). Making career development a reality for dual-career couples. Journal of Employment Counseling, 32(1), 32-45.

Stockard, J. B. (1990). The woman CPA: Career and family. Retrieved Feb 5, 2019, from http://www.nysscpa.org/cpa journal

Sullivan, S. E., \& Mainiero, L. A. (2007). The changing nature of gender roles, alpha/beta careers and work-life issues: Theory driven implications for human resource management. Career 
Development International, 12(3), 238 - 263.

Sullivan, S.E. \& Mainiero, L.A. (2008). Using the kaleidoscope career model to understand the changing patterns of women's careers: Implementing human resource development programs to attract and retain women. Advances in Developing Human Resources, 10(1), 32-49.

Theunissen, B., Vuuren, V. L. J., \& Visser, D. (2003). Communication of job-related information and work-family conflict in dual-career couples. SA Journal of Industrial Psychology, 29(1), 18-25.

The Star Online (2017) Retrieved from https://www.thestar.com.my/news/nation2017/12/12/malaysians-now-enjoying-muchhigher-living-standard/

Ugwu, L. (2009). Dual-career couples: Coping with multiple role stress. Gender and Behaviour, $7(1), 2231-2246$.

Waite, L. J. and Nielsen, M. (2001) 'The rise of the dual-career earner family, '1963-1997', in: R. Hertz and N. C. Marshall (ed.) Working Families. The Transformation of American Home. California: University of California Press.

Winkler, A. E. (1998) Earning of husbands and wives in dual-earners families. Monthly Labour Review, 121 (4): 42-48.

Wood. G. J., \& Lindorff, M. (2001). Sex differences in explanations for career progress. Women in Management Review, 16(4), 152-162.

Ahmad, H., Mokshein, S. E., \& Husin, M. R. (2018). Detecting Item Bias in an Anatomy \& Physiology Test for Nursing Students using Item Response Theory. International Journal of Academic Research in Progressive Education and Development, 7(1), 97-109.

Okeke, M. N., Mbonu, C. M., Ndubuisi, A.N. (2018). Tax Revenue and Economic Development in Nigeria: A Disaggregated Analysis, International Journal of Academic Research in Accounting, Finance and Management Sciences 8 (2): 178-199. 